\title{
Probing the boundaries of Irish memory: from postmemory to prememory and back ${ }^{1}$
}

$\mathrm{I}^{\mathrm{t}}$ thas long been accepted that memory plays a prominent role in the construction of Irish identities and yet historians of Ireland were relatively late in addressing the vogue for memory studies that emerged in the 1980s. Its arrival as a core theme in Irish historical studies was announced in 2001 with the publication of History and memory in modern Ireland, edited by Ian McBride, whose seminal introduction essay - the essential starting point for all subsequent explorations issued the promise that 'a social and cultural history of remembering would unravel the various strands of commemorative tradition which have formed our consciousness of the past' ${ }^{2}$ The volume originated in one of the many academic conferences held in the bicentennial year of the 1798 rebellion, which was part of a decade of commemorations that listed among its highlights the tercentenary of the battle of the Boyne, the sesquicentenary of the Great Famine, and the bicentenaries of the United Irishmen, the Act of Union, and Robert Emmet's rising. The following years produced a boom of studies on Irish memory, which has anticipated another decade of commemorations. Eyes are now set on the centenaries of the Great War, the Irish Revolution and Partition, all of which will undoubtedly generate further publications on memory. It is therefore timely to take stock of this burgeoning field and consider its future prospects.

The current state of the arts is showcased in the collected essays of Memory Ireland, edited by Oona Frawley, which have appeared in four volumes: History and modernity (2011), Diaspora and memory practices (2012), The Famine and the Troubles (2014), and James Joyce and cultural memory (2014; co-edited with Katherine O'Callaghan). Frawley maintains that 'Irish cultural memory must necessarily be less monumental and more fragmented than other counterparts because of Ireland's colonial and postcolonial experience'. ${ }^{3}$ After characterising

${ }^{1}$ The ideas presented in this essay were first tried out in 2005, courtesy of Dr Enda Delaney, in a seminar entitled 'Memory, history and society', co-sponsored by the Department of Sociology and the Research Institute of Irish and Scottish Studies at University of Aberdeen. They were resurrected and regenerated in 2013 for a presentation at the Irish Studies Seminar in London, courtesy of Prof. Ian McBride. Before going to print, they were refined and tested at a workshop of the Irish Memory Studies Network coordinated by Dr Emilie Pine. I would like to thank the participants of these forums for their thoughtful comments.

${ }^{2}$ Ian McBride, 'Memory and national identity in modern Ireland' in Ian McBride (ed.), History and memory in modern Ireland (Cambridge and New York, 2001), p. 42. For a review see Guy Beiner, 'History and memory in modern Ireland' in I.H.S., xxxii, no. 128 (Nov. 2001), pp 600-2.

${ }^{3}$ Oona Frawley, 'Introduction' in Oona Frawley (ed.), Memory Ireland, i: history and modernity (Syracuse, 2011), p. xix. 
Irish memory as 'haphazard' in her introduction to the first volume, she then sharpens the distinction between Memory Ireland and Pierre Nora's Les lieux de mémoire (1984-92), claiming that 'if a kind of monumental memory can operate in France, something we might call "postcolonial memory" has operated in Ireland'.

Frawley's editorship of Memory Ireland embraced eclecticism. She purposely 'resisted the temptation to exert an external pressure on essays to conform to a particular approach to "memory". Contributors were not even required to consider the parameters Frawley outlined in a preliminary 'Theory of cultural memory in an Irish postcolonial context' ${ }^{5}$ Left undefined, memory appears as 'an idea that is in itself phantasmagoric, illusive'. ${ }^{6}$ Consequently, the rich assortment of insightful essays is susceptible to the very conceptual trappings rebuked in the introduction to the first volume, whereby

'memory' has become a catchall term; our persistent use, in Irish studies, of a generic, undefined 'memory' not only leaves vague what kind of memory we are talking about, but also encroaches on other terms and ideas - on our general sense of 'history' as 'memory' and on 'tradition' as a form of 'remembrance'?

The stated goal of Memory Ireland is to 'begin a dialogue within Irish studies of one of its most referenced but neglected critical terms' ${ }^{8}$ Ultimately, however, it mirrors the general state of memory studies, exhibiting an increasing profusion of disparate writings that by and large do not engage with each other. Countless additional publications on Irish memory are to be expected, but, in an incoherent discursive field, the term 'memory' runs the risk of losing its critical edge and succumbing to tautology. It may turn out that the delimiters of McBride and Frawley mark the rise and fall of Irish memory studies, tentatively outlining preand post-memory studies phases of Irish historiography. ${ }^{9}$ Researchers who insist on retaining their interest in memory must now ask themselves what innovative directions can break new ground.

The terminology of memory studies has evolved in an effort to overcome conceptual vagueness. The term 'collective memory', originally developed in the interwar period by the sociologist Maurice Halbwachs, is now often substituted

\footnotetext{
${ }^{4}$ Oona Frawley, 'Toward a theory of cultural memory in an Irish postcolonial context' in Frawley (ed.), Memory Ireland i: history and modernity, p. 29. Cf. Pierre Nora, 'General introduction: between memory and history' in Pierre Nora (ed.), Realms of memory: the construction of the French past, (3 vols, New York, 1996), i, 1-20. Nora's seminal introductory essay has become the standard against which all introductions of national memory collections are measured. It should be acknowledged that the wider project, which Nora directed, incorporated multi-faceted explorations of memory, without endorsing a single uniform working definition of collective memory; see Henry Rousso, 'Un jeu de l'oie de l'identité française' in Vingtième Siècle, xv (July-Sept., 1987), pp 151-4. Nora, however, has been faulted for neglecting France's colonial experiences: see Ann Laura Stoler, 'Colonial aphasia: race and disabled histories in France' in Public culture, xxiii, no. 1 (winter 2011), pp 146-9.

${ }^{5}$ Frawley, 'Introduction', p. xx.

${ }^{6}$ Ibid., p. xvii.

${ }^{7}$ Ibid., p. xviii.

${ }^{8}$ Ibid., p. xxiv.

${ }^{9}$ These distinctions are at best tentative. Just as additional major studies of Irish memory are in the offing, there were several important antecedents to McBride's collection, most notably Joep Leerssen, Remembrance and imagination: patterns in the historical and literary representation of Ireland in the nineteenth century (Cork, 1996).
} 
with 'cultural memory', reflecting the wider 'cultural turn'. ${ }^{10}$ Several other alternatives are also prevalent, the most prominent of which are 'popular memory', 'public memory', and 'social memory'. ${ }^{11}$ A new term - 'postmemory' - has been gaining currency in recent years. It was coined by Marianne Hirsch to designate 'second generation memory', which is 'distinguished from memory by generational distance' and 'characterizes the experience of those who grew up dominated by narratives that preceded their birth'. ${ }^{12}$ The term was notably introduced in a study of family photos of Holocaust survivors and has been widely promoted by Hirsch, most recently in a book, The generation of postmemory. ${ }^{13} \mathrm{At}$ an early stage, it was endorsed by James E. Young, a leading authority on monumental and artistic representations of the Shoah, and has since become widely used in Holocaust studies. ${ }^{14}$ Postmemory, which according to Hirsch 'may usefully describe other second-generation memories of cultural or collective traumatic events and experiences' ${ }^{15}$ has been adopted in more general studies of the cultural legacies of the Second World War. ${ }^{16}$ It has also been applied further afield, for example in studies of children of victims of state terror in South America. ${ }^{17}$

${ }^{10}$ Maurice Halbwachs, The collective memory (New York, 1980); idem, On collective memory (Chicago, 1992). For an anthology of key texts see Jeffrey K. Olick, Vered Vinitzky-Seroussi and Daniel Levy (eds), The collective memory reader (New York and Oxford, 2011); see also Astrid Erll and Ansgar Nünning (eds), Cultural memory studies: an international and interdisciplinary handbook (Berlin and New York, 2008).

11 'Popular memory' was conceived in the early 1980s and later used to great effect by the oral historian Alistair Thomson; see Popular Memory Group, Richard Johnson and Graham Dawson, 'Popular memory: theory, politics, method' in Richard Johnson, Gregor McLennan, Bill Schwartz and David Sutton (eds), Making histories: studies in historywriting and politics (London, 1982), pp 205-52; Alistair Thomson, Anzac memories: living with the legend (Oxford, 1994). For a noteworthy example of a study of 'popular memory' see John E. Bodnar, Remaking America: public memory, commemoration, and patriotism in the twentieth century (Princeton, 1992). For early works on 'social memory' see Peter Burke, 'History as social memory' in Thomas Butler (ed.), Memory: history, culture and the mind (Oxford and New York, 1989), pp 97-113; James Fentress and Chris Wickham, Social memory (Oxford and Cambridge MA, 1992).

12 Marianne Hirsch, Family frames: photography, narrative and postmemory (Cambridge, MA, 1997), p. 22.

${ }^{13}$ Marianne Hirsch, The generation of postmemory: writing and visual culture after the Holocaust (New York, 2012). Hirsch maintains a website dedicated to promulgating her work on postmemory, see http://www.postmemory.net

${ }^{14}$ James E. Young, At memory's edge: after-images of the Holocaust in contemporary art and architecture (New Haven, 2000), pp 2, 5, 38-41. For a recent example, see Brett Ashley Kaplan, Landscapes of Holocaust postmemory (New York, 2011).

${ }^{15}$ Hirsch, Family frames, p. 22.

${ }^{16}$ For example Anne Fuchs, Phantoms of war in contemporary German literature, films and discourse: the politics of memory (Houndmills and New York, 2008), pp 45-76 (chapter on 'Family narratives and postmemory'); Kristin Leigh Kopp and Joanna Niżyńska (eds), Germany, Poland, and postmemorial relations: in search of a livable past (New York and Basingstoke, 2012).

${ }^{17}$ Susana Kaiser, Postmemories of terror : a new generation copes with the legacy of the 'dirty war' (New York, 2005); Alejandra Serpente, 'The traces of "postmemory" in second-generation Chilean and Argentinean identities' in Francesca Lessa and Vincent Druliolle (eds), The memory of state terrorism in the Southern Cone: Argentina, Chile, and Uruguay (New York, 2011), pp 133-56. 
For Hirsch, postmemory is essentially 'delayed, indirect, secondary' in comparison to memory, which is supposed to be 'more directly connected to the past' ${ }^{18}$ In the growing literature, postmemory is not only found in children of those who witnessed historical events but also among their contemporaries, so that the intergenerational remove at the heart of the term is not necessarily dependent on a direct familial relationship. When not restricted to autobiographical recollections passed on from parent to child, the boundaries between memory and postmemory become blurred. For example, in a study of remembrance of Boer War concentration camps, Liz Stanley mused:

The more I thought about Hirsch's term, the more it resonated, but also the more confining it to the second generation seemed unnecessary and seeing memory as 'more directly connected to the past' appeared problematic. ... in a moral sense, we are all secondgeneration, we humans; and all memory is 'post-slash-memory', 'post/memory', because almost immediately marked by representational forms and separated by the absolutism of passing time from the originating events. ${ }^{19}$

Memory studies since Halbwachs have persuasively demonstrated that collective manifestations of remembrance are constructed and repeatedly reconstructed within social frameworks (labelled by Halbwachs 'les cadres sociaux de la mémoire') in which memory is mediated by a plethora of cultural agents and subject to multiple receptions. Since reconstruction, mediation and reception take place both within and beyond the first generation of eye-witnesses, the validity of an essential distinction between an immediate primary memory and a distanced subsidiary postmemory is questionable. ${ }^{20}$

The prefix 'post-' implies that memory proper comes to an end with the passing away of those who experienced the historical events. As this disruption has been specifically associated with present times, the notion of the death of personal memory echoes the wider discursive context of the death of traditional communal memory, as hailed by modernisation theories. Perceptions of crises of memory have been the stimulus for the development of memory studies. This was already evident in fin de siècle modernist writing a century ago. ${ }^{21}$ Even more so, perceived loss of memory is the driving force behind current debates. The decline of 'spontaneous memory' in face of an 'acceleration of history' is central to Nora's thesis, according to which 'lieux de mémoire exist because there are no longer milieux de mémoire, settings in which memory is a real part of everyday existence'. ${ }^{22}$ Similarly, the 'invention of tradition' thesis, as formulated by Eric Hobsbawm, has compellingly put forward the argument that, following 'the secular decline of both old tradition and custom', earlier practices of memory have been replaced with artificially constructed commemorative

${ }^{18}$ Hirsch, Family frames, pp 13, 22.

19 Liz Stanley, Mourning becomes ... post/memory and commemoration of the concentration camps of the South African War 1899-1902 (Manchester, 2006), p. 21. In its hyphenated form, the separation of postmemory from memory becomes redundant.

${ }^{20}$ This problem resembles anthropological criticism of sharp distinctions between oral history (narratives recalling events within an informant's lifetime) and oral tradition (transmitted passed over several generations); see Elizabeth Tonkin, Narrating our pasts: the social construction of oral history (Cambridge, 1992).

${ }^{21}$ See Richard Terdiman, Present past: modernity and the memory crisis (Ithaca and London, 1993).

${ }^{22}$ Nora, 'Between memory and history', p. 1. 
traditions. ${ }^{23}$ For the sociologist Paul Connerton, who previously wrote a landmark study on 'how societies remember', collective amnesia is the sign of contemporary 'post-mnemonic culture' ${ }^{24}$ This doctrinaire insistence on the demise of memory and the advent of an age of postmemory overlooks widespread perseverance of traditions from the past in recycled forms.

Critical rethinking of the end of memory also requires scrutiny of its origins. At a first glance, it may seem that the question of when memory commences can be easily resolved: we intuitively tend to assume that memory follows history and that an event is remembered after it occurs. However, the processing of historical events in memory does not necessitate an interval. As put by the anthropologist Edwin Ardener, "There are, indeed, plenty of grounds for saying that "memory" of history begins when it is registered. It is encoded "structurally". ${ }^{25}$ Considering remembrance in Ireland, McBride came to a similar realisation: 'It can be argued, indeed, that the arrangement of experience through narrative frames is such a basic part of cognition that events are encoded with meaning as they actually occur. ${ }^{26}$ I would like to suggest that this line of thinking can be pushed even further, beyond the apparent simultaneity of history and memory, and that, paradoxical as it may first seem, memory can precede history. Already as an event is unfolding, it is understood and interpreted through reference to memories of previous events, which can be labelled prememory. In turn, traditions of prememory shape and influence the subsequent memory of the event.

To appreciate the role of prememory, consider, for example, the construction of Protestant-loyalist social memory of the 1798 Rebellion. The repeated re-issue over the eighteenth century of Sir John Temple's The Irish Rebellion (1646) and Archbishop William King's, The state of the Protestants of Ireland under the late King James's government (1691), alongside various tributary publications, propagated enduring memories of the rebellions of the seventeenth century, which evoked emotive images of sectarian atrocities that harked back to Foxe's Book of martyrs. These pervasive memories influenced the ways in which loyalist Protestants perceived the United Irish insurrections in 1798 and how they would remember that cataclysmic year. ${ }^{27}$ Previously constructed memories noticeably informed the views of Sir Richard Musgrave, described by James Kelly as the "chief ideologist and pre-eminent propagandist of Irish ultraProtestant loyalism'. Emulating a tradition, established with the 1641 depositions, of documenting personal recollections for partisan political purposes, he solicited testimonies from 'suffering loyalists' as source material for a history of $1798 .{ }^{28}$ Published shortly after the events in three editions (1801-2),

${ }^{23}$ See Eric Hobsbawm, 'Introduction: inventing traditions' in Eric Hobsbawm and Terence Ranger (eds), The invention of tradition (Cambridge, 1983), pp 1-14.

${ }^{24}$ Paul Connerton, How modernity forgets (Cambridge and New York, 2009); cf. Paul Connerton, How societies remember (Cambridge, 1989).

${ }^{25}$ Edwin Ardener, 'The construction of history: "vestiges of creation"' in Elizabeth Tonkin, Maryon McDonald and Malcolm Chapman (eds), History and ethnicity (London and New York, 1989), p. 25.

${ }^{26}$ McBride, 'Memory and national identity', p. 8.

${ }^{27}$ See James Kelly, "We were all to have been massacred": Irish Protestants and the experience of rebellion' in Thomas Bartlett, David Dickson, Dáire Keogh and Kevin Whelan (eds), 1798: a bicentenary perspective (Dublin, 2003), pp 312-30 (especially pp 313-15).

${ }^{28}$ Musgrave depositions (T.C.D., MS 871). 
Musgrave's Memoirs of the different rebellions in Ireland became, in the words of Kevin Whelan, the 'matrix of memory' for 1798 and remained a seminal text in Protestant unionist polemics for over a century. ${ }^{29}$ Memory of Ninety-Eight was evidently rooted in prememory that antedated 1798 .

Niall Ó Ciosáin's perceptive meditation on the memory of the Great Irish Famine made a similar point, observing in the popular memory found in folklore collections that informants draw on a repertoire of images, motifs and short narratives, many of which predate the Famine' ${ }^{30}$ Considering the wider prevalence of such mnemonic traditions, McBride argued that 'memories take root most successfully when they are patterned in accordance with the culture's accepted customs of telling stories about itself' ${ }^{31}$ Charles Frederic Bartlett, a pioneer of experimental psychology, recognised the formative role of prememories, which he labelled schemata, noting in his landmark study Remembering (1932): 'I shall call this fundamental process of connecting a given pattern with some setting or scheme: effort after meaning. ${ }^{32}$ Schema theory has since been fruitfully developed in the cognitive sciences. ${ }^{33}$ More recently, Astrid Erll has discussed such dynamics in regards to historical cultural memory through use of terms developed by Richard Grusin for media studies: premediation and remediation. ${ }^{34}$

Memory maintains a dialectical relationship with history. Most studies of memory and history, including McBride's collection, begin with the preliminary assumption that 'memory is itself historically constructed'. ${ }^{35}$ Awareness of prememory, however, can turn this postulation on its head. Just as memory is constructed by history, at some level, history is apparently constructed by memory, insofar as historical events were originally experienced with reference to pre-existing memories. It is important to note that the notion of recycling memory does not imply simple acts of repetition but calls attention to reflexive processes of reconstruction, reinvention, and regeneration. An understanding of the dynamics of renewal reveals continuities of memory. The absence of a clear rupture between biographical memory and intergenerational memory presents grounds for redefining postmemory along different lines from the conception of a defining break proposed by Hirsch.

${ }^{29}$ James Kelly, Sir Richard Musgrave, 1746-1818: ultra-Protestant ideologue (Dublin, 2009), especially pp 90-150; Kevin Whelan, The tree of liberty: radicalism, Catholicism and the construction of Irish identity 1760-1830 (Cork, 1996), pp 131-75 (especially pp 135-45); Stuart Andrews, Irish rebellion: Protestant polemic, 1798-1900 (Basingstoke and New York, 2006), especially pp 20-50.

${ }^{30}$ Niall Ó Ciosáin, 'Famine memory and the popular representation of scarcity' in McBride (ed.), History and memory, p. 102.

${ }^{31}$ McBride, 'Memory and national identity', p. 36.

32 F. C. Bartlett, Remembering: a study in experimental and social psychology (Cambridge and New York, 1995; orig. edn 1932), p. 20.

${ }^{33}$ See for example, Jean M. Mandler, Stories, scripts and scenes: aspects of schema theory (Hillsdale, NJ, 1984).

34 Astrid Erll, 'Remembering across time, space, and cultures: premediation, remediation and the "Indian Mutiny" in Astrid Erll and Ann Rigney (eds), Mediation, remediation, and the dynamics of cultural memory (Berlin and New York, 2009), pp 10938. See also J. David Bolter and Richard A. Grusin, Remediation: understanding new media (Cambridge, MA, 1999); Richard A. Grusin, Premediation: affect and mediality after 9/11 (Basingstoke and New York, 2010).

${ }^{35}$ McBride, 'Memory and national identity', p. 4. 
Contrary to postmodern historicizing of memory, which denies the endurance of 'living memory', we are, as argued by Raphael Samuel, still dwelling within 'theatres of memory'. ${ }^{36}$ Accepting that memory persists in a continuous present, and that it also has a past in the form of prememory, suggests possibilities for contemplating prospects for future developments of memory. The cyclical nature of remembrance implies that, even when certain recollections lose their vitality within contemporary society, the decline of memory is not necessarily terminal. A more imaginative conceptualisation of postmemory would recognise that dormant memories can be rejuvenated. In identifying 'two lives of folklore', the folklorist Lauri Honko argued that traditions which have been collected, documented and conserved in an archive can later be resurrected and gain a 'second life', once again acquiring social currency. ${ }^{37}$ This revival is another form of postmemory.

The ability to resuscitate memory was demonstrated recently in the public release of the archival collections of the Bureau of Military History, which has breathed new life into academic and popular perceptions of 1916. The reminiscences of veterans of the Irish Revolution that were documented by army personnel three to four decades later in a remarkable oral history project were inaccessible for half a century. Since 2003, when this repository of sources was first made available to researchers, the witness statements have been consulted widely by historians, notably by Fearghal McGarry, who has used them as 'the spine' for his 'story of the Rising from within and below' and has also published an edited collection of statements. ${ }^{38}$ The recent digitalisation of the collection, which is now freely available to all members of the public (as well as the ongoing phased release online of the records of the Military Service Pensions Collection, which also presents retrospective statements of veterans) is set to effectively democratise and reshape the memory of the Irish Revolution as it approaches its centennial. ${ }^{39}$ In this process of regeneration, postmemory recharges older memories, using them as prememory for new reconstructions of memory.

It is generally assumed that memory diminishes as we move away from the remembered moment and, ever since the experiments of Hermann Ebbinghaus with the retention of nonsense syllables in the late-nineteenth century, this process has been plotted along a 'forgetting curve' ${ }^{40}$ In the sophisticated model of cultural memory put forward by Jan and Aleida Assman, the vitality of

${ }^{36}$ Raphael Samuel, Theatres of memory: past and present in contemporary culture (revised edn, London, 2012).

${ }^{37}$ Lauri Honko, 'The folklore process' in Pekka Hakamies and Anneli Honko (eds), Theoretical milestones: selected writings of Lauri Honko (Helsinki, 2013), pp 29-54. Cf. Nora's critical comments on the function of an oral history archive as a lieu de mémoire: 'It is no longer a more or less intentional record of actual memory but a deliberate and calculated compilation of a vanished memory. It adds a secondary or prosthetic memory to actual experience': Nora, 'Between memory and history', pp 9-10.

${ }^{38}$ Fearghal McGarry, The Rising, Ireland, Easter 1916 (Oxford and New York, 2010), p. 4; idem, Rebels: voices from the Easter Rising (Dublin, 2011).

${ }^{39}$ See the essay by Eve Morrison that is featured on the website in order to encourage use of the collection: Eve Morrison, 'Bureau of Military History witness statements as sources for the Irish Revolution'; http://www.bureauofmilitaryhistory.ie/abouthistoricalessays.html

${ }^{40}$ Hermann Ebbinghaus, Über das Gedächtnis: Untersuchungen zur experimentellen Psychologie (Leipzig, 1885); first translated into English by Henry A. Ruger and Clara E. Bussenius as Memory: a contribution to experimental psychology (New York, 1913). 
remembrance is retained beyond personal recollections of those who experienced historical events and can be transmitted over three generations as a fluid 'communicative memory' (in which grandparents pass on vivid narratives to grandchildren and their peers) before it is formulated into a more stable form. ${ }^{41}$ However, by defining prememory and redefining postmemory, we are faced with the more wide-ranging scope of regenerative memory. As I have proposed elsewhere, the longue durée of memory can be examined historically by undertaking an archaeology of social memory. This requires tracing reconstructions of memory from a terminus ante quem of an ethnographic present, in which memory was last documented, back to the terminus post quem of the historical events. In such a model, prememory signifies the elementary building blocks of memory, which predate the historical events, and postmemory refers to additional reconstructions, subsequent to when the main records of memory were deposited in archives. ${ }^{42}$

The ebbs and flows, which can be identified within the seemingly endless continuum of repeatedly regenerated memory, do not correspond to a linear timeline. A constructivist understanding of the reformulation of memory reveals that it not only wanes but, when regenerated, can also wax. Therefore, the vitality of memory is not dependent on proximity to historical events. Moreover, in some cases, immediacy can prove to be a hindrance so that the conditions for popular revival of memory emerge at a remove. An example can be found in the stifling of official remembrance of Irish participation in the Great War and its rehabilitation after the passing of almost a century.

Emerging academic interest in Irish remembrance of the First World War, which has been particularly noticeable since the publication of Keith Jeffery's Ireland and the Great War (2000), acquired wider resonance when Sebastian Barry's historical novel A long long way (2005) was selected for Dublin's 'One city one book' event in 2007. The markedly enthusiastic reception of the 2008 Thomas Davis lecture series Our war, edited for publication by John Horne (and originally broadcast on RTÉ Radio 1), offers further evidence of the reawakening of memory. A reviewer commented: 'at a time when other nations are concerned that the passing of the last veterans might bring about forgetting of the lessons and experiences of the First World War, in Ireland it seems that we are only now beginning to remember. ${ }^{43}$ This rediscovery of public memory was brought to the

${ }^{41}$ See Jan Assman, 'Collective memory and cultural identity' in New German Critique, lxv (1995), pp 125-33; idem, 'Communicative and cultural memory' in Peter Meusburger, Michael Heffernan and Edgar Wunder (eds), Cultural memories: the geographical point of view (Dordrecht, Heidelberg, London and New York, 2011), pp 15-27; Aleida Assmann, 'Memory, individual and collective' in Robert E. Goodin and Charles Tilly (eds), The Oxford handbook of contextual political analysis (Oxford New York, 2006), pp 210-24.

${ }^{42}$ For an elaboration on the methodology for an archaeology of social memory see Guy Beiner, Remembering the Year of the French: Irish folk history and social memory (Madison, WN, 2006), pp 313-19.

${ }^{43}$ Shane Hegarty, 'Bringing the war back home' in Irish Times, 8 Nov. 2008, p. B4. The Thomas Davis lecture series was broadcast on RTÉ Radio 1 from late October to late December 2008 and was accompanied by the publication of John Horne (ed.), Our war: Ireland and the Great War (Dublin, 2008). For the publicity and public debate see http://www.rte.ie/1918 
fore in the media coverage of Queen Elizabeth II's visit in 2011 to the much neglected National War Memorial Gardens in Islandbridge, as depicted in a newspaper headline: 'Forgotten Irish war dead honoured by queen's visit'. ${ }^{44}$ The war is now unreservedly recognised as a cornerstone of Ireland's decade of commemorations. ${ }^{45}$ Apparently, recalcitrant memories can be repressed and muted for several generations only to later resurface in new contexts and flourish as postmemory.

The model of memory as an open-ended series of recycled representations outlined above may be particularly appealing for cultural studies, as it encourages discovery of recurring motifs, tropes and images that were repeatedly readapted throughout Irish history and can perhaps be mapped in a 'mnemosyne atlas' (to use a concept devised by Aby Warburg in the early twentieth century). ${ }^{46}$ This approach may even offer grist for the mill of ethnosymbolist interpretations of national identity. ${ }^{47}$ However, historians are most likely to find that historical experience is lost in an ever-expanding trans-generational meta-memory. In a famous essay on 'The sociological problem of generations' (1927), Karl Mannheim argued that generations are not biological units but socio-cultural constructs, which are constituted by the memories of those who were at formative ages when memorable historical events occurred. He made a forceful case for 'a fundamental distinction between appropriated memories and personally acquired memories' ${ }^{48}$ This line of reasoning requires reconsideration of the significance of remembrance for the generation that personally experienced historical events. In order to go beyond a macro understanding of memory and to call attention to the emotional investment involved in constructing memory on a micro level, I will propose yet another way of imagining prememory and postmemory.

For the sake of differentiation, the conceptualisation outlined above can be categorised as regenerative prememory and postmemory. The alternative redefinition of the terms, which can be labelled affective prememory and postmemory, focuses on those who agonised over how certain domineering events, or causes to which they were deeply devoted, would be perceived by later generations and utilised their privileged position as witnesses of history to

${ }^{44}$ Irish Examiner, 19 May 2011. For the deliberately 'de-centred' choice of location of the National War Memorial Gardens see Nuala Christina Johnson, Ireland, the Great War, and the geography of remembrance (Cambridge and New York, 2003), pp 108-11.

${ }^{45}$ See John Horne and Edward Madigan (eds), Towards commemoration: Ireland in war and revolution, 1912-1923 (Dublin, 2013).

${ }^{46}$ See Christopher D. Johnson, Memory, metaphor, and Aby Warburg's atlas of images (Ithaca, NY, 2012).

${ }^{47}$ For recognition of the role of memory by advocates of ethnosymbolism see John Hutchinson, 'Warfare, remembrance and national identity' in Athena S. Leoussi and Steven Grosby (eds), Nationalism and ethnosymbolism: history, culture and ethnicity in the formation of nations (Edinburgh 2007), pp 42-52. For an example of applying an ethnosymbolic approach to the study of Irish history and memory see Jonathan GithensMazer, Myths and memories of the Easter Rising: cultural and political nationalism in Ireland (Dublin, 2006).

${ }^{48}$ Karl Mannheim, Essays on the sociology of knowledge (London, 1952), 286-320 [the emphasis in the quotation appears in the original]. Mannheim's theory has since been affirmed by empirical studies; for a recent example see Howard Schuman and Amy Corning, 'Generational memory and the critical period: evidence for national and world events' in Public Opinion Quarterly, lxxvi, no. 1 (Jan. 2012), pp 1-31. 
assume the role of custodians of memory. Prememory here refers to their anticipations and expectations in advance of the events, and postmemory refers to their subsequent anxieties and angst over the changing nature of memory. According to this approach, prememory can be noticed in attempts to predetermine how history would be remembered. This is apparent, for example, in Robert Emmet's famous speech from the dock in which he tried to rehabilitate his reputation by explicitly appealing to future generations through such utterances as 'I wish that my memory and name may animate those who survive me', and 'let no man attaint my memory'. An observer at the trial noticed that 'he seemed to consider himself as rising into a Martyr'. By striving to influence the memory of the failed rising of 1803 and presenting himself as an exemplary republican martyr even before he was executed, Emmet consciously engaged in his own mythogenesis. ${ }^{49}$

Postmemory, in this second reinterpretation, denotes the frustrations of those who sense that their ability to influence social memory of events in which they had participated is failing. An example of such apprehensions can be found in the midnineteenth-century communications of the elderly veterans of the 1798 Rebellion in counties Antrim and Down and their relatives with Richard Robert Madden, the sympathetic historian of the United Irishmen. By the 1840s, the members of this dwindling coterie of radicals were mostly reconciled with the Union and yet considered themselves faithful guardians of a beleaguered eighteenth-century republican memory, which was threatened by hostile loyalist history writing. They believed that their trust had been abused by Samuel McSkimin, a historian from Carrickfergus, who wrote antagonistic accounts of the rebellion after interviewing some of them. The 74-year-old former rebel James Hope complained in 1838 that McSkimin was guilty of 'misrepresentation' and five years later 73-year-old Mary Ann McCracken, sister of Henry Joy McCracken - the executed leader of the rebels in Antrim, detected a 'mass of fabrication' in McSkimin's writings. They made unsuccessful efforts to acquire McSkimin's papers upon his death in 1843 in order 'that all the falsehoods and misrepresentations they contain may not go down to posterity as historical truth' and that 'truth and falsehood might be separated while there were living witnesses competent to do so'. To ensure that their version of memory would be preserved for future generations, they wholeheartedly provided Madden with personal recollections and family traditions. The inherent nervousness underlying postmemory is reflected in one of McCracken's letters to Madden, in which she noted that Hope was 'extremely anxious about your forthcoming volume respecting the North' ${ }^{50}$

\footnotetext{
${ }^{49}$ Marianne Elliott, Robert Emmet: the making of a legend (London, 2003), pp 80-5. Among the different versions of Emmet's speech that were in circulation after his trial, one variation has him explicitly declaring: 'It is a claim on your memory, rather than on your candour, that I am making': Patrick M. Geoghegan, Robert Emmet: a life (Dublin, 2002), p. 247. See also Guy Beiner, 'The legendary Robert Emmet and his bicentennial biographers' in The Irish Review, xxxii (2004), pp 98-104.

${ }^{50}$ Richard Robert Madden papers (T.C.D., MS 873/96, 155, 156, 627); Leon Ó Broin papers (N.L.I., MS 29,950); see also Richard Robert Madden, The United Irishmen: their lives and times (Dublin, 1846), 3rd ser., no. 1, pp 223 and 396. McSkimin's history of 1798 was published posthumously as Samuel McSkimin, Annals of Ulster; or, Ireland fifty years ago (Belfast, 1849) and republished as History of the Irish Rebellion in the year 1798; particularly in Antrim, Down and Derry (Belfast, 1853).
} 
Although the concerns of affective prememory and postmemory are projected into the future, they are grounded in a present context in which people struggle to make sense of their lives by constructing the memory of key historical events in their lifetime. This preoccupation, which is particularly meaningful for those who participated in the remembered events, also resonates with a wider audience of people from a younger generation, who find themselves reflecting on the significance of the presence of historical eyewitnesses and the relevance of the stories they recount. Affective prememory and postmemory is therefore a more general social phenomenon which is dependent on mediations in which local historians and other collectors who document, archive and disseminate the testimonies of eyewitnesses play a crucial role.

Prememory and postmemory in the second sense outlined here are expressions of impassioned beliefs, which can also determine actions. The promoters of a favoured prememory often turn a blind eye on a multiplicity of other possible outcomes and thus became wilful prisoners of their own desires. Given the unpredictability of history, more often than not, remembrance develops along different lines than what had been originally hoped for and attitudes to the past inherently change over time, creating conditions for the anxieties of postmemory. The uncovering of these innermost yearnings and trepidations can therefore offer valuable historical insight into the thoughts and motivations of people in the past. Moreover, sharp-eyed historians would do well to dig up traces of latent prememories, which momentarily surfaced in expectations of eventualities that did not materialise. For example, our understanding of the memory and forgetting of the Civil War would benefit not only from revisiting the neglected postmemory anxieties of supporters of the Treaty, which were examined by Anne Dolan,${ }^{51}$ but also from consideration of frustrated prememory amongst members of the anti-Treaty side, who had anticipated a different turn of events in which republican insurgency against the Irish Free State would be publicly celebrated in years to come. A similar argument can be made in favour of excavating the hopeful prememories (found in diaries and personal correspondence) and the bitter postmemories (found in memoirs and in the Bureau of Military History testimonies) of those who had a 'bad 1916' and felt let down by the results of the Irish Revolution.

I have proposed two very different directions for the study of memory: regenerative prememory and postmemory, which broadly surveys cycles of remembrance that range over extended periods of time, and affective prememory and postmemory, which closely examines deliberations over grassroots construction of memory in a single generation. Despite the conceptual differences between the models, an amalgamation between the two is conceivable. The analytical framework of prememory and postmemory in the narrow affective definition could be applied to each generation within the extended regenerative timeline of memory, in order to expose tensions embedded in the subtle negotiations through which memory is reconstructed. This is fertile ground for a better understanding of 'memory booms', which are moments of heightened rediscovery and reinvention in which new interpretations of memory are put forward and contested.

${ }^{51}$ See Anne Dolan, Commemorating the Irish Civil War: history and memory, 19232000 (Cambridge, 2003). 
The current decade of commemorations in Ireland is a case in point. Unlike the golden jubilee of the Easter Rising a half century ago, the planned celebrations will not be attended by veterans and will not be perturbed by the postmemory anguish of the embittered wives and sisters of the 1916 rebels, who vocally protested against the official commemorations in $1966 .{ }^{52}$ However, there seems to be a reappearance of controversy along lines that loosely resemble the timeworn labels of 'revisionists' and 'traditionalists'. Back in the 1980s, concerns were voiced over the extent to which new interpretations of Irish history could remould historical consciousness. Anxieties and expectations over the fate of collective memory were apparent on all sides of the debate, not only in the agitated reactions of those who felt that their convictions were under assail by the iconoclasm of historical revision and that previously established narratives needed to be reaffirmed, but also by those committed to revising nationalist history, who expressed doubts about their ability to influence 'the public mind'. ${ }^{53}$ Similarly, the recurring eruptions of the so-called 'Peter Hart debate', most recently re-emerging in the heated exchange over reviews of the Trinity College Dublin History Workshop publication Terror in Ireland edited by David Fitzpatrick (and in particular the contribution 'Kilmichael revisted' by Eve Morrison) are laden with the burdens of affective prememory and postmemory. ${ }^{54}$ In this acrimonious controversy, which cuts deeper than the venting of personal enmities and opinionated politics, the authority of eyewitnesses is still called upon, even though they are no longer around to participate in the debate.

From a distance of three or four generations after the events, historians such as Roy Foster in his recently published The vivid faces: making a revolution in Ireland, c. 1890-1923 can now look back critically at how the 'Irish revolutionary generation' constructed memory and uncover the underlying considerations of affective prememory and postmemory. It is now also possible to examine the memories of the children of the revolutionaries (the subject of forthcoming research by Caoimhe Nic Dháibhéid) and to reveal the workings of regenerative remembrance. The centennial contributions, which unknowingly address the theme of prememory and postmemory, will no doubt feed into reformulations of Irish memory in our time. Clearly, there is fertile ground for the application of more sophisticated interpretative analysis of how historical memories were formed and reformed in Ireland.

GUY BEINER

Department of History, Ben-Gurion University of the Negev

52 See Roisín Higgins, Transforming 1916: meaning, memory and the fiftieth anniversary of the Easter Rising (Cork, 2012), pp 40, 83.

${ }^{53}$ See, for example, the concluding comments in Roy Foster, Modern Ireland 16001972 (London, 1988), p. 595.

${ }^{54}$ See the reviews and replies published online in the Dublin Review of Books (http://www.drb.ie/essays/the-history-of-the-last-atrocity; http://www.drb.ie/reviews/ reply-to-john-regan) and Reviews in History (http://www.history.ac.uk/reviews/review/ 1303), as well as running commentary spread over several issues of the popular magazine History Ireland. 